\title{
Effect of Shading on the Growth of Some Common Weeds of the Semi-Arid Tropics ${ }^{1}$
}

\author{
S. V. R. Shetty, M. V. K. Sivakumar, and S. A. Ram ${ }^{2}$
}

\begin{abstract}
Light is one of the major factors influencing crop-weed balance. The influence of shading on the growth, leaf area, dry matter production, and seed production of some common weeds of the semiarid tropics was investigated in a field study at ICRISAT Research Center near Hyderabad, India, during the 1978 and 1979 rainy seasons. Different shade treatments were achieved by erecting rectangular bamboo frames over each plot. The weeds studied were Cyperus rotundus L., Digitaria ciliaris (Retz.) Koeler, Celosia argentea L., Acanthospermum hispidum DC., Tridax procumbens L., Dactyloctenium aegyptium (L.) P. Beauv., and Amaranthus viridis L. At $90 \%$ shading plant height was reduced to $30 \%$ of the control with Celosia and Tridax. Digitaria and Dactyloctenium showed 70 to $80 \%$ reductions in leaf area index (LAI) at $90 \%$ shading. Dry matter production in Digitaria, Dactyloctenium, and Acanthospermum was reduced up to $80 \%$ at higher shading levels. In Cyperus, the effect of decreasing light levels on plant height was not pronounced, but the LAI and dry matter production were severely affected. Photosynthetic photon flux density (PPFD) measurements showed a negative correlation between levels of shading and the seed production in these weeds.

The study indicated that by manipulating crop canopies to create desired shading, substantial weed suppression could be achieved. The agronomic significance of these results is discussed in the light of the weed-suppressing capacity of crop canopies in different cropping systems of the semiarid tropics that may complement other control measures to obtain better weed management.
\end{abstract}

Additional index words: Cyperus, Digitaria, Celosia, Acanthospermum, Tridax, Dactyloctenium, Amaranthus, Photosynthetic Photon Flux Density, Height, Dry matter, Leaf area index, Seed production.

T $\mathrm{T}$ is well known that intensive cropping and the use of crop management practices that improve the shading capacity of crops increase the efficiency of cultural and chemical weed control methods (Harwood and Bantilan, 1974). Shading observed in any given crop canopy is a dynamic feature that varies with the relative rates of crop and weed growth, time of the day, time of the year, crop duration, and location. Competitive capacity of plants is governed, in part, by the efficiency with which they intercept light, and by the capacity to suppress the growth and development of other plants, such as shade-sensitive weeds-as occurs in the rapid shading created by crop canopies (Keeley and Thullen, 1978). Light interception in several crops and crop combinations has been monitored at ICRISAT Center. Sivakumar and Virmani (1980) suggested that intercropping of short-duration and fast-growing cereal crops such as maize (Zea mays L.) or sorghum [Sorghum bicolor (L.) Moench] with the slow growing pigeonpea [Cajanus cajan (L.) Millsp.] could establish a quick ground cover, enabling high PPFD interception (high shading) levels. Natarajan and Willey (1980) showed from measurements of light interception at ground level that a sorghum/pigeonpea intercrop could attain $80 \%$ inter-

\footnotetext{
${ }^{1}$ Authorized for publication as ICRISAT Journal Article No. 179. Received 6 July 1981 .

${ }_{2}$ Agronomist, principal agroclimatologist, and technical assistant (Weed Science), respectively, Farming Systems Research Program, International Crops Research Institute for the Semi-Arid Tropics (ICRISAT), Patancheru, Andhra Pradesh 502 324, India.
}

ception in about 50 days after planting. They also suggested that after the sorghum harvest, poor light interception by pigeonpea could be increased by higher plant population density and better plant distribution. Reddy and Willey (1981) reported from light interception measured at ground level that a groundnut/pearl millet [Arachis hypogaea L./Pennisetum americanum (L.) Leeke] intercrop could achieve $75 \%$ light interception in about 50 days after planting. These studies showed the high shading capacity of different cropping systems of the semiarid tropics, thus indicating the capacity to suppress the growth of associated weeds. Though we have observed differential weed growth in these different cropping systems, we were not able to quantify the effect of these shading levels on the associated weeds because those experiments were conducted with different objectives and necessitated weed-free conditions.

In the semiarid tropics the potential for managing weeds through plant competition is being encouraged because other methods of weed control may not be economical for the farmer with limited resources (Shetty, 1980). The potential of plant competition for weed control in the semiarid tropics has been demonstrated (Shetty and Krantz, 1980). Previous work at ICRISAT has shown that intercropping could have an added advantage of weed suppression, particularly if those crops that are more efficient in shading weeds are used as intercrops (Rao and Shetty, 1977; ICRISAT, 1980; Shetty and Rao, 1979). Crops with good seedling vigor such as cowpea [Vigna unguiculata (L.) Walp.] and mung bean [Vigna radiata (L.) Wilczek], with their early ground cover suppressed weed growth substantially, decreased weeding costs, and increased the efficiency of hand-weeding when used as intercrops with sorghum. The possibility of using crop/weed competition for light as a component of weed management prompted us to study the tolerance of some common weeds of the semiarid tropics to different levels of shading.

\section{MATERIALS AND METHODS}

The experiment was conducted during the rainy seasons of 1978 and 1979 at the ICRISAT Research Center near Hyderabad, India. The soil is a medium-deep Alfisol classified as a fine, mixed, member of the hyperthermic family of Udic Rhodustalfs. It is low in organic matter, $\mathbf{N}$ and P.

The experiment was a split-plot with four replications, and each replicate consisted of 16 plots measuring $3 \times 2$ $\mathrm{m}$ in 1978 and $2.4 \times 2.4 \mathrm{~m}$ in 1979 . Shade treatments were the main plots and weed species were the sub-plots. A pure stand of each species was attained by transplanting in rows on 28 and 29 June during the 1978 and 1979 growing seasons, respectively, 15-day-old seedlings raised in paper pots. To minimize the effect of interplant competition, a wide spacing of $25 \times 25 \mathrm{~cm}$ was maintained. Other volunteer weeds were removed periodically by hand-weeding.

Seven major weeds of the semiarid tropics were selected for the study. Weeds studied in 1978 were Cyperus rotundus L., Digitaria ciliaris (Retz.) Koeler, Celosia argentea L., and Acanthospermum hispidum DC. During the 1979 rainy 
season, to gain additional information, the last three weed species were substituted by three other weed species belonging to the same families to which 1978 test species also belong. Cyperus, being a perennial and noxious weed, was studied in both years. Thus, in 1979 Cyperus rotundus L., Dactyloctenium aegyptium (L.) P. Beauv., Amaranthus viridis $\mathrm{L}$., and Tridax procumbens $\mathrm{L}$. were included. A brief description of these weeds is given below:

1. Acanthospermum hispidum DC., a weed introduced from South America, is a very gregarious and aggressive plant of the family Compositae. It is an erect, branched, herbaceous annual thriving best in light soils. It is recognized by its spiny achenes and forking branches bearing opposite leaves.

2. Amaranthus viridis $\mathrm{L}$. is an erect, much branched annual herb. It is very common in Alfisols. It is recognized by long terminal panicles with minute green flowers. It belongs to the family Amaranthaceae.

3. Celosia argentea $\mathrm{L}$. is one of the major weeds of loamy dry soils, belonging to the family Amaranthaceae. It is an erect, branched, herbaceous annual with pinkish flowers packed in stout cylindrical spikes.

4. Cyperus rotundus L., which is considered an obnoxious weed, belongs to family Cyperaceae. It is an erect herb with perennial underground stems spreading over a large area by means of tubers. It is cosmopolitan and thrives in all kinds of soils under varying conditions of moisture and temperatures.

5. Digitaria ciliaris (Retz.) Koeler, is an erect annual herb of the family Gramineae. It is common in light soils, propagated by seeds and stems rooting at lower nodes.

6. Dactyloctenium aegyptium (L.) P. Beauv. is a short annual herb with creeping or erect branches, belonging to the family Gramineae. Its flowers are arranged on digitate spikes and it is propagated mainly by seeds.

7. Tridax procumbens $\mathrm{L}$. an introduced weed has become naturalized. It belongs to the family Compositae. It is a herb with branching on all sides. This plant produces a large number of seeds (achenes) that are widely dispersed with the help of pappus.

Shade treatments were achieved by erecting rectangular bamboo frames covered with hardboard strips $1 \mathrm{~cm}$ thick and $3 \mathrm{~cm}$ wide running at right angles to each other over the plot. Different levels of shading attained by noon time at ground level in the 1978 season were 90,80 , and $68 \%$ of control, whereas in the 1979 season they were $90,80,75$, and $60 \%$ of control. Height of the shade frames over each plot was adjusted according to the growth of the weed species during the growing season. For example at the end of the experiment shade frame over Cyperus was at $50 \mathrm{~cm}$ height while over Celosia the height of the shade frame was at $150 \mathrm{~cm}$. In order to reduce light penetration from the sides, tall-growing cultivars of sorghum were grown around each plot. Steps were taken to ensure that the weed species were subjected to no water stress by means of frequent irrigations.

Interception of photosynthetic photon flux density (PPFD) under each shade frame was monitored at weekly intervals throughout the growing season, using four traversing quantum sensors (LI 190S LAMBDA Instruments Corporation, Lincoln, Neb.). ${ }^{3}$ Incident radiation measured under different shade levels in the two growing seasons is given in Table 1. The data presented for selected dates show that the shade frames were effective in achieving within $\pm 4 \%$, the desired levels of shading in each treatment. The number of new shoots, leaves, and plant height were recorded at monthly intervals during the growing season. Weed dry matter was

\footnotetext{
${ }^{3}$ Mention of commercial products or companies does not imply Mention of commercial products or companies does not imply
endorsement or recommendation by ICRISAT over others of a similar nature.
}

Table 1. Incident Photosynthetic Photon Flux Density (PPFD) measured under different levels of shading on selected dates during the two growing seasons.

\begin{tabular}{|c|c|c|c|c|c|c|}
\hline \multirow[b]{2}{*}{ Dates } & \multicolumn{6}{|c|}{ Levels of shading $(\%)$} \\
\hline & $90(90) \dagger$ & $80(80)$ & $68(75)$ & (60) & Control & L.S.D. $(0.05)$ \\
\hline & & & & $\mathrm{m}^{2} / \mathrm{sec}$ & & - \\
\hline \multicolumn{7}{|l|}{1978} \\
\hline 18 Aug. & 114 & 151 & 276 & .- & 855 & 3.5 \\
\hline 25 Aug. & 131 & 239 & 418 & .. & 1,287 & 22.3 \\
\hline 4 Sept. & 105 & 343 & 448 & .- & 1,596 & 15.8 \\
\hline 4 Oct. & 174 & 342 & 431 & -. & 1,409 & 15.8 \\
\hline \multicolumn{7}{|l|}{1979} \\
\hline 19 Aug. & 126 & 224 & 278 & 384 & 994 & 6.9 \\
\hline 26 Aug. & 86 & 184 & 252 & 381 & 958 & 13.9 \\
\hline 4 Sept. & 157 & 258 & 356 & 571 & 1,504 & 10.6 \\
\hline 30 Sept. & 198 & 310 & 414 & 621 & 1,597 & 9.7 \\
\hline
\end{tabular}

$\dagger$ Figures in parenthesis apply to shade levels observed in 1979 growing season.

determined by sampling plants in a quadrat of $1 \mathrm{~m}^{2}$ and drying them to constant weight in a forced draft oven at $65 \mathrm{C}$. The leaf area of different weed species was measured with an automatic leaf area meter. Seed and tuber production under different levels of shading were recorded and expressed as a percentage of production in the control (i.e., no shading).

\section{RESULTS AND DISCUSSION}

Plant height, leaf area index (LAI), and dry matter for the 1978 rainy season are shown in Fig. 1. Maximum reduction in plant height due to shading occurred in the case of Celosia. Ninety percent shading resulted in $70 \%$ reduction in plant height, 16 weeks after planting. Shading had little effect on Digitaria where reduction in plant height at the $90 \%$ shade level was only $26 \%$. Acanthospermum exhibited intermediate behavior in that the reduction in plant height at the $90 \%$ shade level was $50 \%$ but the pattern in reduction was similar to that exhibited by Celosia. The reduction in final plant height observed in the case of Cyperus was only 30 at $90 \%$ shade level. However, the effects were more pronounced in this weed early in the growing season, whereas other weeds showed the major effects later in the growing season.

The effects of shading on LAI and dry matter were different from the effects on height. At $90 \%$ shading, Cyperus showed the maximum reduction in LAI of $72 \%$, Digitaria 70\%, Acanthospermum 60\%, and $\mathrm{Ce}$ losia $50 \%$. The reduction in LAI due to shading was fairly gradual throughout the growing period in contrast to the effects of height.

Total dry matter production of weeds also showed seasonal changes due to shading that varied with different weed species. Digitaria and Acanthospermum showed $80 \%$ reduction at $90 \%$ shading followed by Cyperus and Celosia with 60 and $40 \%$ reduction, respectively. The rate of dry matter production was similar for all weeds at all shade levels, though in the case of Acanthospermum and Digitaria the no-shading treatment showed a larger increase in dry matter accumulation later in the growing season.

In 1979, seasonal changes in plant height for different weed species (Fig. 2) showed that the maximum reduction to the extent of $70 \%$ occurred in Tridax at 
the maximum shade level of $90 \%$. Among the other species, Amaranthus showed almost no reduction, and Dactyloctenium and Cyperus showed only marginal reductions primarily due to the prolonged growth of the inflorescence axis.

As in 1978 the effects of shading on LAI and dry matter were more pronounced in 1979 also. Increased shading resulted in increased reductions in LAI and dry matter in all weed species. Increasing the shade level from 60 to $90 \%$ resutled in a reduction in LAI from 75 to $20 \%$ as compared to control treatment in the case of Dactyloctenium, while in Amaranthus and Cyperus the drop was from 80 to $30 \%$. Maximum effect of shading on LAI (about $40 \%$ of maximum) in Tridax occurred at the initial shade level of $60 \%$. Increasing the shade level to $90 \%$ resulted in a further LAI reduction of only $20 \%$. The effects of varied shade levels on dry matter production were more pronounced in the case of Dactyloctenium and Cyperus, while with Amaranthus and Tridax they were less pronounced.
The effects of different levels of shading on LAI, dry matter production, and seed production at the time of harvest were recorded for all the species in each year. These are illustrated in Fig. 3 and 4. It can be observed that during 1978, though Digitaria exhibited a different response as far as LAI is concerned, all the annual weeds showed similar trends in dry matter reduction. In 1979 Dactyloctenium exhibited a steep reduction in LAI as well as dry matter production due to increasing shading levels. Though Amaranthus suffered a significant reduction in LAI due to increased shading, dry matter reduction was rather gradual. Tridax showed only gradual and minimal reduction both in LAI and drymatter.

Besides corroborating findings on seasonal changes in growth patterns of weeds Fig. 3 also reveals that seed production is significantly affected by shading levels. Among six annual weeds, Celosia, Acanthospermum, Amaranthus, and Dactyloctenium showed substantial reduction in seed production at low shading levels. Seed production was not reduced substan-

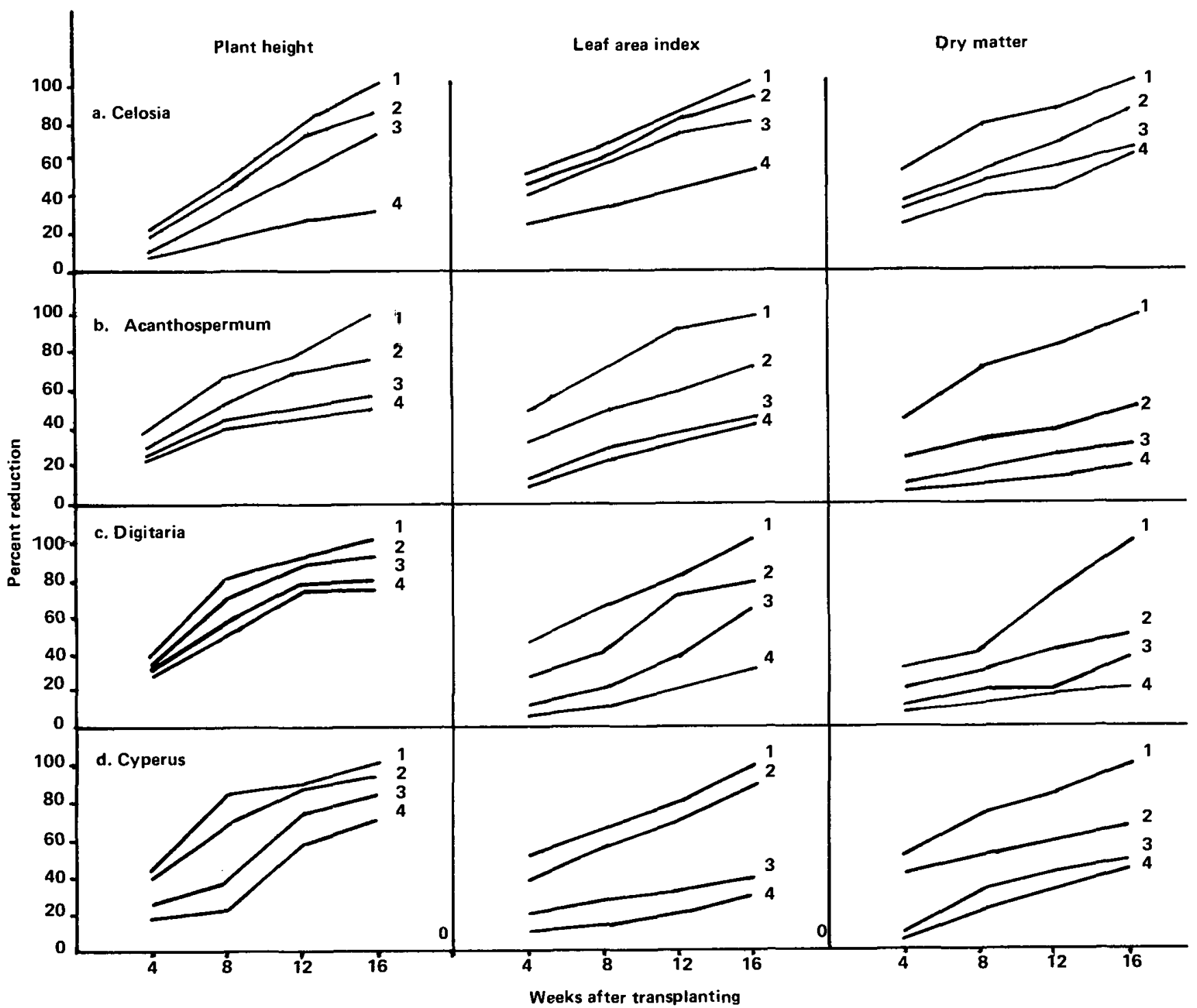

Fig. 1. Seasonal changes in plant height, leaf area index, and dry matter for different weeds under varying shade levels during $1978(1=$ No shading (control); $2=68 \%$ shading, $3=80 \%$ shading; $4=90 \%$ shading). 
tially at low shading levels with Digitaria and Tridax.

As noted above, only Cyperus was studied in both seasons. Data on plant height, LAI, dry matter, and tuber production collected over the two seasons were pooled and their relationship to transmission of PPFD is shown in Fig. 4. The effect of decreasing transmission of PPFD or increased shading on LAI, dry matter and tuber production was more pronounced than on plant height. A very high correlation was noticed between dry matter and PPFD transmission and tuber production and PPFD transmission.

Growth patterns of different weeds under investigation (Fig. 1 and 2) suggest that shade levels of about $80 \%$ or more, fairly early in the growing season, may be necessary to suppress the weed growth to the extent of $50 \%$. With particular reference to different cropping systems studied at ICRISAT Center, some implications of this are discussed below.

\section{CONCLUSION}

Light interception studies at ICRISAT Center have shown that varying production practices and cropping systems will affect the shading capability of the crop canopy (Natarajan and Willey, 1980; Reddy and Willey, 1981; Sivakumar and Virmani, 1980). The results from the present study confirm earlier findings which showed that the differential shading ability of the crop canopies was one of the factors which determined the crop/weed competition balance, and thus contributed to differential crop productivity observed in different cropping systems.

Keeley and Thullen (1978) studied the light requirements of yellow nutsedge (Cyperus esculentus L.) and estimated the light competition potential of several crops by measuring the interception of light by crop

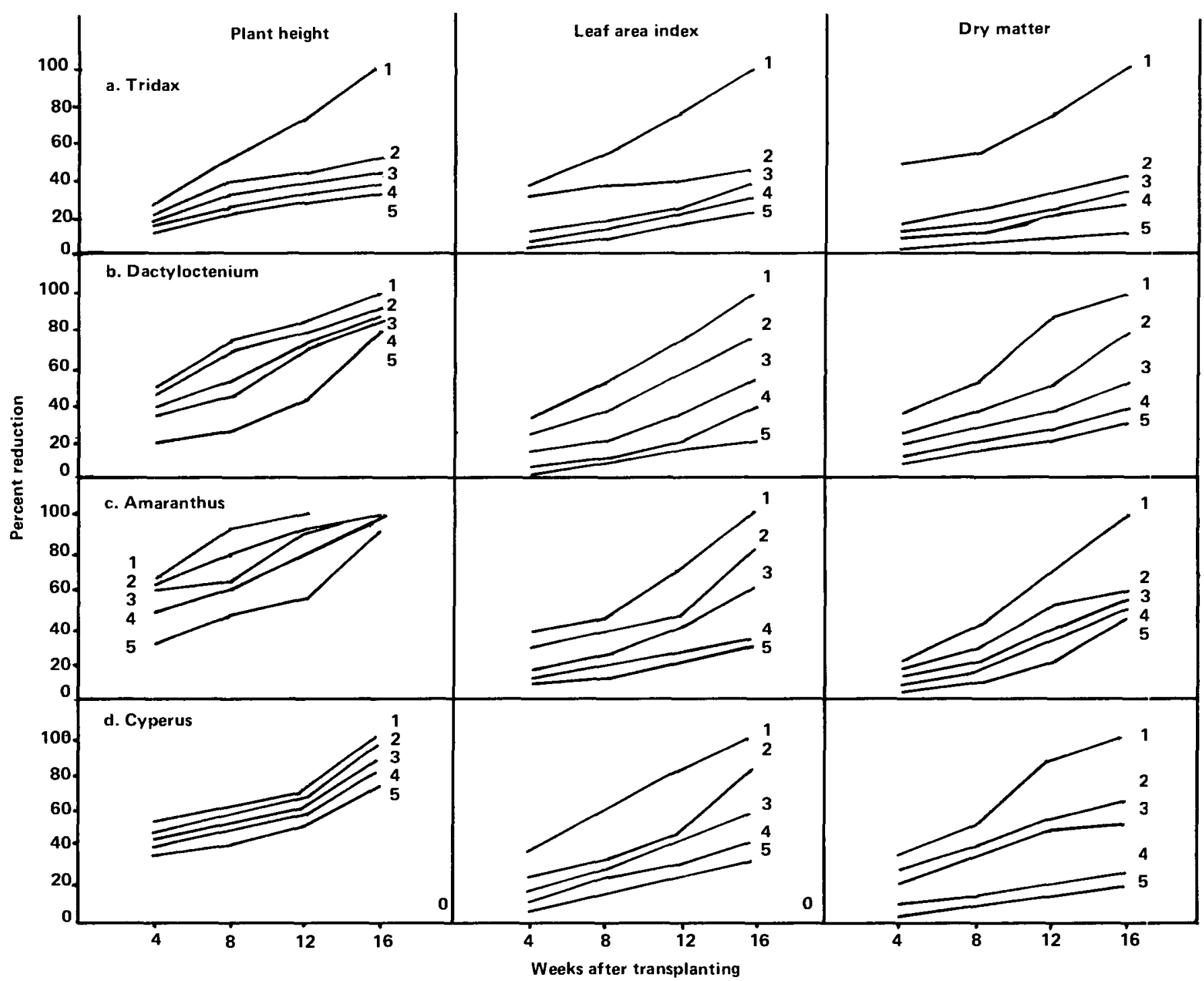

Fig. 2. Seasonal changes in plant height, leaf area index, and dry matter for different weeds under varying shade levels during $1979(1=$ No shading (control); $2=60 \%$ shading, $3=75 \%$ shadding; $4=80 \%$ shading; $5=90 \%$ shading). 
canopies. Among many crops studied by them sorghum and cowpea were highly efficient competitors for light. Our earlier studies on weed-smother cropping systems (Shetty and Krantz, 1978) further confirmed their findings. The reduction in dry matter production of weeds observed in our present study clearly suggests that at higher shade levels the effect can be particularly severe on these weeds and thus would be beneficial to component crops. These results strengthened our earlier hypothesis that the additional shading achieved by the introduction of additional smother crops such as cowpea or mung bean contributed to the weed growth suppression and thus resulted in decreasing weeding costs. Quick ground cover early in the growing season by smother-crop canopies might have had severe effects on a weed such as Cyperus which is shade-sensitive, particularly during the early part of the growing season. Though we did not take light measurements in different smother-cropping systems, the results, of the present study further confirm the concept that light can be one of the major factors influencing crop/weed balance. Studies are under way to quantify the light use pattern by crops and weeds in such smother-cropping systems.

The results of the seed and tuber counts taken at the end of the life cycle highlight the effect of shading on weed propagation (Fig. 3 and 4). Among annual weeds $90 \%$ shading reduced seed production to $10 \%$, while 32 to $40 \%$ light interception resulted in only $55 \%$ seed production. This trend was also observed with Cyperus where $90 \%$ shading reduced tuber production by $89 \%$. This is significant in that a small amount of shading not only reduced weed growth and development and thus weed competition with crops, but also
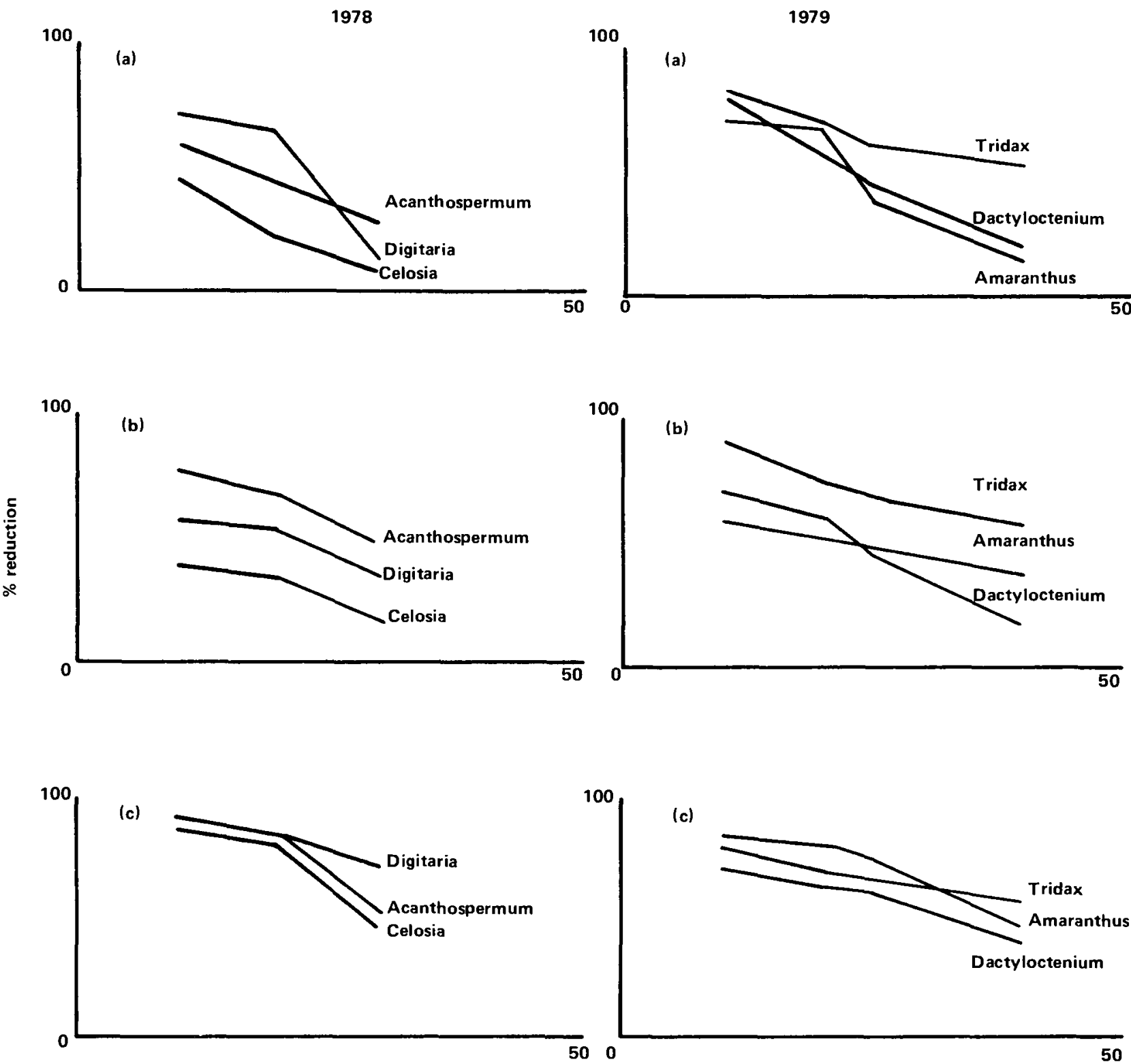

Transmission of PPFD (\%)

Fig. 3. Effect of light transmission (PPFD) on (a) final Leaf Area Index (b) final dry matter production, and (c) seed production of different weeds. 

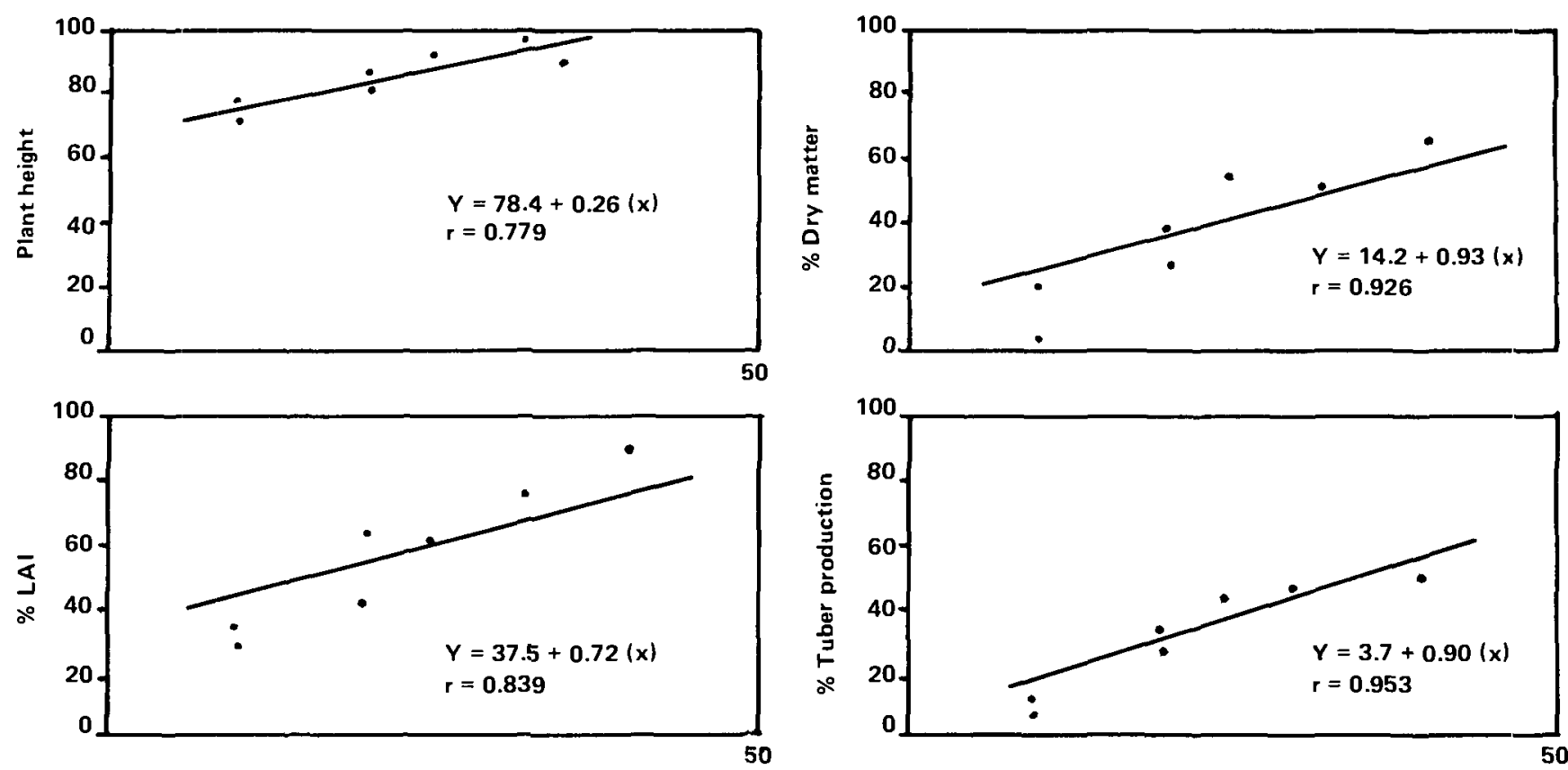

Transmission of PPFD (\%)

Fig. 4. Relationship between light transmission (PPFD) and the plant height, LAI, dry matter, and tuber production of Cyperus rotundus.

adversely affected weed reproduction. Therefore, shading through crop canopies should contribute to a gradual reduction in the growth of a weed community. It should be noted also that, whereas shading may assist in controlling some species, other shadetolerant species will become dominant in subsequent years unless other effective control measures are undertaken.

Of the weed species studied it appears that, in the case of Digitaria, Acanthospermum, Cyperus, Dactyloctenium, Tridax, and Amaranthus which showed more sensitivity to shading, some degree of muchneeded early weed control could be achieved through the adoption of approximate management practices that provide shading in the early growth period. Among these weeds Cyperus seemed highly shadesensitive. This is encouraging in that Cyperus is the most noxious perennial weed of the semiarid tropics, and is difficult to eradicate by any one method of weed control. Growth suppression and reduction in the rate of propagation through shading by crop canopy should complement other control practices.

In general, the study indicated that among the sev. eral test species dicotyledonous weeds are less shadesensitive than monocotyledons. This observation has practical significance in that, across the semiarid tropics, grasses are usually the predominant weeds and the broad-leaved weeds tend to occur late in the crop season when crops are well established and weed competition is no longer significant (Shetty and Krantz, 1980). Growth suppression due to increased shading was relatively less with Celosia and Tridax and, therefore, these weeds can be considered more shade-tolerant. Further, it may be predicted that shading through the crop canopy could encourage these particular weeds as they encounter minimum competition from other weeds. Celosia and Tridax are also considered as major weeds of Alfisols.

The choice of an appropriate cropping system cannot be made on the basis of its shading and potential weed suppression capacity alone. The desired yield level and environmental constraints in adopting the appropriate cropping system are also important. A combination of principles combining competiveness between crops and weeds, and chemical and mechanical weed control, could result in the maximization of complementarity in different weed control methods and the resulting benefits.

\section{LITERATURE CITED}

Harwood, R, R., and R. T. Bantilan. 1974. Integrated weed management: 2. Shifts in composition of the weed community in intensive cropping systems. Philip. Weed Sci. Bull. 1(2): $: 7-59$.

ICRISAT. 1980. International Crops Research Institute for the Semi Arid Tropics Annual Report, 1978-1979. India: ICRISA T, Patancheru, A.P. 502 324, India.

Keeley, P. E., and R. J. Thullen. 1978. Light requirement of yellow nutsedge (Cyperus esculentus) and light interception by crops. Weed Sci. 26(1):10-16.

Natarajan, M., and R. W. Willey. 1980. Sorghum/pigeonpea intercropping and effects of plant population density. I. Growth and yield. II. Resource use. J. Agric. Sci. 95(4):51-65.

Rao, M. R., and S. V. R. Shetty. 1977. Some biological aspects of intercropping systems on crop-weed balance. Indian J. Weed Sci. 9(1):32-43.

Reddy, M. S., and R. W. Willey. 1981. Growth and resource use studies in an intercrop of pearl millet/groundnut. Field Crop Res. 4:13-24.

Shetty, S. V. R. 1980. Some agro-economic aspects of improved weed management systems in Indian Semi-Arid Tropiss. p. 899-909. In $1980 \mathrm{Br}$. Crop Prot. Counc. Conf., Proc. (Brighton, U.K.)

reseand B. A. Krantz. 1978. Approaches to weed management research for the semi-arid tropics. p. 115-127. In O. Akobandu (ed.) Weeds and their control in the humid and subhumid tropics. Ibadan, Nigeria: International Institute for Tropical Agriculture. 
and -1980 . Weed Research at ICRISAT (International Crops Research lnstitute for the Semi-Arid Tropics). Weed Sci. 28(4):451-454.

sorghum/pigeonpea and pearl millet/groundnut intercrop systems -some observations. In Proc. Int. Intercropping Workshop, ICRISAT, Patancheru, A.P., India.
- and M. R. Rao, 1977. Weed management studies in pigeonpea based on intercropping. p. 665-673. In 6th Asian Pacific Weed Sci. Soc. Conf., Proc. (Jakarta, Indonesia).

Sivakumar, M. V. K. and S. M. Virmani. 1980. Growth and resource use of maize, pigeonpea and maize/pigeonpea intercrop in an operational research watershed. Exp. Agric. 16:377-386. 